\title{
SEXUALIZATION, SEX DISCRIMINATION, AND PUBLIC SCHOOL DRESS CODES
}

\author{
Meredith Johnson Harbach *
}

\section{INTRODUCTION}

If you follow social media, you may have noticed the rash of reporting on battles over public school dress codes and their effects on and implications for girls. ${ }^{1}$ Complaints have been registered across the country, including here in Virginia. ${ }^{2}$ For example, in September 2014 at the Maggie Walker Governor's School, administrators announced over the PA system that school officials would be performing a shorts-length spot check. ${ }^{3}$ Any girls found to be in violation of the rule would be forced to change; if ten girls broke the rule, all girls would be banned from wearing shorts for a day. ${ }^{4}$ In Evanston, Illinois, school officials banned leggings because they were "too distracting" for boy students. ${ }^{5}$ In New Jersey, high school girls were prohibited from wearing strapless dresses to prom because they, too, were distracting. ${ }^{6}$ In Florida, a new student who inadvertently violated her school's skirt rules was made to wear a so-called "shame suit": red sweatpants and

* Associate Professor, University of Richmond School of Law. Thanks to Kimberly Jenkins Robinson for helpful comments during the drafting of this paper, and to John O'Malley for research assistance. I also thank John Hogan and the editorial staff of the Richmond Law Review for their excellent work on this piece during the editing process.

1. See, e.g., Rebecca Lurye, Beaufort High Student's Dress-Code Protest Part of Larger Social Media Trend, BEAUFORT GAZETTE (Oct. 29, 2015), http://www.islandpacket.com /news/local/community/beaufort-news/article41853426.html.

2. See id.; Elizabeth Ballou, Richmond's Maggie L. Walker Governor's School Protested Dress Code Sexism in the Best Way, BusTLE (Oct. 6, 2015), http://www.bustle.com/arti cles/41715-richmonds-maggie-l-walker-governors-school-protested-dress-code-sexism-inthe-best-way.

3. Ballou, supra note 2.

4. Id.

5. Eliana Dockterman, When Enforcing School Dress Codes Turns into Slut Shaming, TIME (Mar. 25, 2014), http://time.com/36997/when-enforcing-school-dress-codes-turnsinto-slut-shaming/

6. Id. 
an oversized neon yellow shirt that said "Dress Code Violation."7 Several commentators have likened these scenarios to "slut shaming," and girls around the country have organized under the Twitter hashtag \#imnotadistraction.

These anecdotes have triggered concerns over sex stereotyping and institutionalizing sex discrimination. Over the last several years, public school dress codes and their impact on girls have generated a wave of news articles and editorials in publications such as the New York Times, ${ }^{9}$ the Washington Post, ${ }^{10}$ and Time magazine. ${ }^{11}$ The Huffington Post has an entire section devoted to collecting reports and commentary on school dress codes. ${ }^{12}$

The emerging controversy raises a number of important and fraught questions for schools, students, and parents. For instance, how do school dress codes intersect with the increasing sexualization of girls in American culture? Is there a point beyond which contemporary fashion, favored by girl students, raises concerns about sexualization? How do we balance school interests in educational mission and student interest in identity formation and self-determination? How do community norms and expectations influence school decisionmaking? How can students, schools, and the larger community come together to talk constructively about school dress codes in a way that advances the schools' legitimate interests, but avoids sexualization and sex discrimination?

This essay joins the conversation about sexualization, sex discrimination, and public school dress codes to situate current debates within in the broader cultural and legal landscapes in which they exist. My aim is not to answer definitively the questions I pose above. Rather, I ground the controversy in these broader contexts in order to better understand the stakes and to

7. Eliza Murphy, Student Forced to Wear 'Shame Suit' for Dress Code Violation, ABC NEwS (Sept. 4, 2014, 5:43 PM), http://abcnews.go.com/US/student-forced-wear-shame-suitdress-code-violation/story?id=25252041.

8. Dockterman, supra note 5.

9. Peggy Orenstein, Opinion, The Battle Over Dress Codes, N.Y. TIMes (June 13, 2014), http://www.nytimes.com/2014/06/14/opinion/the-battle-over-dress-codes.html.

10. Charlotte Canning \& Frances Schwentker, Opinion, A Mother and Daughter Take on the Dress Code, WASH. POST (June 2, 2015), https://www.washingtonpost.com/news/par enting/wp/2015/06/02/a-mother-and-daughter-take-on-the-dress-code/.

11. Laura Bates, Opinion, How School Dress Codes Shame Girls and Perpetuate Rape Culture, TIME (May 22, 2015), http://time.com/3892965/everydaysexism-school-dress-codes -rape-culture/.

12. School Dress Code, HUFFINGTON POst, http:/Www.huffingtonpost.com/news/sch ool-dress-code/ (last visited Feb. 19, 2016). 
s Code Violation."? scenarios to "slut ganized under the

sex stereotyping or the last several pact on girls have als in publications $~$ Post $^{10}$ and Time section devoted to ess codes. ${ }^{12}$

of important and parents. For inith the increasing ere a point beyond udents, raises conschool interests in identity formation orms and expectastudents, schools, alk constructively the schools' legit$\mathrm{x}$ discrimination?

alization, sex disituate current degal landscapes in initively the questroversy in these the stakes and to

ress Code Violation, $\mathrm{ABC}$ -forced-wear-shame-suit-

s, N.Y. TIMEs (June 13, -dress-codes.html.

ther and Daughter Take ingtonpost.com/news/par $\mathrm{de} /$.

irls and Perpetuate Rape exism-school-dress-codes

glean insights into how schools, students, and communities might better navigate dress code debates.

In Part I, I develop the broader cultural context in which school dress codes are situated by exploring recent research concerning the increased sexualization of girls in American culture, and then explaining how these concerns map onto the dress code setting. In Part II, I consider the broader legal terrain of sex discrimination in schools and identify particular questions raised by dress codes. Finally, in Part III, I use insights from these broader contexts to offer observations about how schools and the communities they serve might move forward productively in resolving dress code disputes. Ultimately, I argue schools can and should play a positive role in counteracting sexualization and harmful stereotypes about girls and dress in public schools.

\section{STudent Dress AND SEXualization : THe Cultural CONTEXT}

The dress code controversy operates within a larger cultural context-one in which women are frequently sexualized and portrayed as "sex objects" valued primarily for their sexual appeal. ${ }^{13}$ Increasingly in the United States, it is not just women. Instead, the sexualization of girls and girlhood is recognized as widespread and problematic. ${ }^{14}$ According to the American Psychological Association ("APA"), sexualization occurs when:

- a person's value comes only from his or her sexual appeal or behavior, to the exclusion of other characteristics;

- a person is held to a standard that equates physical attractiveness (narrowly defined) with being sexy;

- a person is sexually objectified, that is, made into a thing for others' sexual use rather than seen as a person with the capacity for independent action and decision making; and/or

- sexuality is inappropriately imposed upon a person. ${ }^{15}$

13. Kaitlyn Graff et al., Too Sexualized to be Taken Seriously? Perceptions of a Girl in Childlike vs. Sexualized Clothing, 66 SEX RoLES 764, 764 (2012).

14. AM. PSYCHOLOGICAL ASS'N, TASK FORCE ON THE SEXUALIZATION OF GIRLS, REPORT OF THE APA TASK FORCE ON THE SEXUALIZATION OF GIRLS 2 (2007), http://www.apa.org/pi /wpo/sexualization.html [hereinafter APA].

15. Id. at 2 . 
The APA posits that the sexualization of girls manifests in three related contexts: cultural sexualization (media, advertising, and products), sexualization by others (parents, teachers, and peers), and self-sexualization. ${ }^{16}$ The consequences of girls' sexualization are both deep and broad. For girls, sexualization can negatively impact cognitive and physical function, mental and physical health, sexuality, and their attitudes and beliefs about gender and sexual roles. ${ }^{17}$ Sexualization of girls may also hinder the abillity of boys and men to interact intellectually with girls and women, which is necessary for males to develop intimacy with female partners. ${ }^{18}$ Women suffer the same sorts of consequences from sexualization as do girls and also experience discrimination and subordination in the workplace as a result. ${ }^{19}$ At a societal level, sexualization may increase the overall incidence of sexism and bias, limit girls' educational aspirations and performance, and contribute to the harassment, violence, and exploitation of girls. ${ }^{20}$

Dress plays a complicated role in the sexualization of girls. Identify formation is an important feature of adolescence in Western cultures. ${ }^{21}$ And clothing is marketed to girls as a means of expressing identity and individuality. ${ }^{22}$ Clothing is thus both an artifact of the sexualization of girls in our culture and also part of the larger process of identity formation over which girls exercise some control. ${ }^{23}$

As a cultural contributor to sexualization, girls' dress (and cosmetics) contribute to sexualized images of girls by providing opportunities for increasingly young girls to wear clothing designed to highlight female sexuality. And most recently, researchers have observed the production and marketing of "sexy" clothing in child and teen sizes. These cultural images provide girls with a template on which to construct their own behaviors, self-concepts, and identities. ${ }^{24}$

16. Id. at $4-18$.

17. Id. at $20-27$.

18. Id. at 28 .

19. Id. at $28-30$.

20. Id. at $30-34$.

21. Id. at 20 .

22. Id. at 13; Kaitlin Graff et al., supra note 13, at 764 .

23. APA, supra note 14 , at 13 .

24. Id. at 14 . 
girls manifests in nedia, advertising, its, teachers, and zes of girls' sexual. ralization can neg. mental and physiliefs about gender so hinder the abilith girls and womimacy with female onsequences from liscrimination and At a societal level, 1ce of sexism and performance, and loitation of girls. ${ }^{20}$

lalization of girls. of adolescence in girls as a means ng is thus both an re and also part of hich girls exercise

girls' dress (and girls by providing wear clothing denost recently, rearketing of "sexy" l images provide ir own behaviors,
But as cultural consumers, girls also exercise some agency over choice of dress. They understand that, given the sexualizing messages in our culture, they may secure status and social privilege by adopting and expressing this cultural norm. ${ }^{25}$ And when navigating these choices, they engage in a process of "selfobjectification," whereby they internalize cultural perspectives on their physical selves, conceiving of themselves in sexual terms preoccupied with physical attractiveness. ${ }^{26}$ Consequently, many parents perceive their daughters as wanting sexualized clothing and accessories and resistant to less sexualized alternatives. ${ }^{27}$ Importantly, however, girls do not exercise these "choices" in a vacuum. Instead, as explored above, their choices are influenced and encouraged by the larger cultural context within which they are situated. ${ }^{28}$ In the end, girls must walk a fine line between conforming to cultural expectations and not being perceived as too sexual. $^{29}$

Students, parents, and others have a number of concerns about public school dress codes and their impact on female students. One concern is that many dress codes are explicitly genderspecific, targeting girls but not boys, or are at least selectively enforced such that they impact female students disproportionately. ${ }^{30}$ Student discipline includes removal from class, receiving detention, being sent home, or forced to wear a "shame suit" indicating she has violated the school dress code. ${ }^{31}$ Female students are powerfully affected by these policies and many express a profound sense of injustice. ${ }^{32}$ The consequences of being "dress coded" have a negative impact on student learning and participation. Beyond the immediate disruption resulting from removal, detention, and

25. Id. at 17 .

26. Id. at 18,21 .

27. Id. at 17 .

28. Id. at 18

29. See Rebecca Raby, 'Tank Tops Are Ok but I Don't Want to See Her Thong,': Girls' Engagements With Secondary School Dress Codes, 41 You't \& SoC'Y 333, 349 (2010).

30. See, e.g., Li Zhou, The Sexism of School Dress Codes, THE ATLANTIC (Oct. 20, 2015), http://www.theatlantic.com/education/archive/2015/10/school-dress-codes-are-probl ematic/410962/ (providing an example of how dress codes often target female students).

31. Gail Sullivan, New Kid at School Forced to Wear 'Shame Suit' for Dress Code Violation, WASH. POST (Sept. 5, 2014), https://www.washingtonpost.com/news/morning-mix/ wp/2014/09/05/new-kid-at-school-forced-to-wear-shame-suit-for-dress-code-violation/ (mentioning in-school suspension and wearing a 'shame suit' as punishment for dress code violations); Zhou, supra note 30 (noting that girls could be given detentions or sent home as punishment for dress code violations).

32. See Bates, supra note 11. 
the like, studies suggest that a preoccupation with physical appearance based on sexualized norms disrupts mental capacity and cognitive function. ${ }^{33}$

Consistent with the research on sexualization of girls, many are concerned about the larger symbolic messages that dress codes and their enforcement send to students and society. A common thread among school justifications for sex-specific dress codes is that provocative clothing will distract their male classmates or make male teachers feel uncomfortable. ${ }^{34}$ A number of commentators thus maintain dress codes communicate that girls' bodies are inherently sexual, provocative, dangerous, and that harassment is inevitable. ${ }^{35}$ Dress codes and their enforcement can impose sexuality on girls even when they do not perceive themselves in sexual terms. ${ }^{36}$ Gender study scholars report that dress codes generally have negative ramifications for women, sending a message that exposing the female body is bad. ${ }^{37}$ Laura Bates of The Everyday Sexism Project characterizes the dress code phenomenon as "teach[ing] our children that girls' bodies are dangerous, powerful and sexualized, and that boys are biologically programmed to objectify and harass them." ${ }^{38}$ Thus, dress codes can constitute a type of "everyday pedagogy," reproducing normative gender and sexuality preferences. ${ }^{40}$

In sum, the current controversy over public school dress codes operates within a larger context in which girls are increasingly portrayed and see themselves in sexualized terms, harming girls and others while having broader societal effects. Based on this cultural context, I next turn to explore the legal backdrop in which dress codes function.

33. APA, supra note 14, at 21.

34. Bates, supra note 11.

35. Id.

36. Id.

37. Shannon McMahon, How Dress Codes Makes Things Worse for High School Girls, BoSTON.COM (May 14, 2015, 3:39 PM), http://www.boston.com/news/nation/2015/05/14/ how-dress-codes-make-things-worse-for-high-school-girls/56GhUPJ1'sp5CsEi4L6HxFP/sto ry.html.

38. Bates, supra note 11

39. Shauna Pomerantz, Cleavage in a Tank Top: Bodily Prohibition and the Discourses of School Dress Codes, 53 ALTA. J. EDUC. RES. 373, 374 (2007).

40. Raby, supra note 29 , at 352 . 
with physical apmental capacity

on of girls, many ssages that dress is and society. A sex-specific dress their male classle. ${ }^{34}$ A number of unicate that girls' gerous, and that $r$ enforcement can ot perceive themreport that dress women, sending a ${ }^{37}$ Laura Bates of dress code pheodies are dangere biologically pro, dress codes can ducing normative

chool dress codes are increasingly $\mathrm{ms}$, harming girls ts. Based on this egal backdrop in

e for High School Girls, news/nation/2015/05/14/ $1 \mathrm{sp} 5 \mathrm{CsEi} 4 \mathrm{~L} 6 \mathrm{HxFP} / \mathrm{sto}$

\section{STUDENT DRESS AND SEX DISCRIMINATION: THE LEGAL CONTEXT}

In this section, I turn to examine the legal principles governing the intersection, of school prerogatives and student interests in dress codes disputes. Of course, this is not the first occasion when school dress codes have been challenged. Beginning in the $1960 \mathrm{~s}$ and 1970 s, early cases challenged sex-based school grooming policies. ${ }^{41}$ And in subsequent decades, students challenged dress codes and uniform policies as violating their First Amendment speech and expression rights. ${ }^{42}$ This latest generation of dress codes implicates evolving dress preferences for girls, including clothing like skinny jeans, leggings, yoga pants, and sleeveless shirts. $^{43}$

Although students sometimes challenge public school dress codes and uniform requirements on First Amendment grounds, ${ }^{44} \mathbb{I}$ will limit my analysis in this article to the particular issues raised by the most recent spate of objections: sex stereotypes and sex discrimination. ${ }^{45}$ In the event of alleged gender discrimination in schools, students have available to them both ${ }^{46}$ a Section 1983 action for violation of Equal Protection ${ }^{47}$ and a claim under Title IX of the Education Amendments of 1972 ("Title IX"). ${ }^{48}$ According-

41. See Breese v. Smith, 501 P.2d 159, 161 (Alaska 1972); Johnson v. Joint Sch. Dist. No. 60, 508 P.2d 547, 548-49 (Idaho 1973); Scott v. Bd. of Educ., 305 N.Y.S.2d 601, 603, 606 (N.Y. Sup. Ct. 1969).

42. See, e.g., Karr v. Schmidt, 460 F.2d 609, 613-14 (5th Cir. 1972) (discussing existence of the First Amendment right to wear long hair).

43. See, e.g., Emanuel County School System Student Uniform Quick Reference Chart, EMANUEL CTY. SCH. SYS., https://eboard.eboardsolutions.com/Meetings/TempFolder/Poli cies/4064_JCDB-E\%281\%29_10045_Exhibits.pdf (last visited Feb. 19, 2016).

44. See, e.g., McCallum v. Cash, 585 F.3d 214, 220 (5th Cir. 2009); Jacobs v. Clark, 526 F.3d 419, 423 (9th Cir. 2008); Blau v. Fort Thomas Pub. Sch. Dist., 401 F.3d 381, 385 (6th Cir. 2005); see also Laurel Grbach, Note, Transgender Student Dress: Free Speech and Protected Expression in Public Schools, 22 TEMP. POL. \& C.R. L. REV. 526, 534-35 (2013); Wendy Mahling, Note, Secondhand Codes: An Analysis of the Constitutionality of Dress Codes in the Public Schools, 80 MINN. L. REV. 715, 716 (1996); Natalie Smith, Note, Eliminating Gender Stereotypes in Public School Dress Codes: The Necessity of Respecting Personal Preference, 41 J.L. \& EDUC. 251, 253-54 (2012).

45. See Jennifer L. Greenblatt, Using the Equal Protection Clause Post-VMI to Keep Gender Stereotypes Out of the Public School Dress Code Equation, 13 U.C. DAVIS J. JUV. L. \& POL'Y 281, 284-85, 292 (2009); Jeremiah R. Newhall, Sex-Based Dress Codes and Equal Protection in Public Schools, 12 APPALACHIAN J.L. 209, 212, 224 (2013).

46. Title IX does not preclude a section 1983 action for constitutional violations. See Fitzgerald v. Barnstable Sch. Comm., 555 U.S. 246, 256 (2009).

47. 42 U.S.C. $\$ 1983$ (2012).

48. 20 U.S.C. $\$ 1681$ (a) (2012). 
ly, I will begin with Fourteenth Amendment Equal Protection doctrine, then turn to statutory analysis under Title IX of the Civil Rights Act, and finally turn to the analogous line of cases considering sex-based dress codes in employment. I will then consider the legal questions these principles raise for school dress codes.

\section{A. Sex Discrimination under the Fourteenth Amendment and Title IX}

\section{Equal Protection}

One of the foundational constitutional tenets I teach every year in my Children and the Law Course is that although not always recognized as such, children in public schools have constitutional rights. In the watershed case Tinker $v$. Des Moines Independent Community School District, ${ }^{49}$ the Supreme Court confirmed that students do not shed their constitutional rights when they enter school. ${ }^{50}$ Yet children's constitutional rights are not identical to those of adults. ${ }^{51}$ In particular, a long line of Supreme Court cases following Tinker has affirmed that children's constitutional rights may be circumscribed in light of special circumstances within the school setting. ${ }^{52}$ The Court has qualified students' constitutional rights in the contexts of the First, ${ }^{53}$ Fourth, ${ }^{54}$ and Fourteenth Amendments. ${ }^{55}$

Moving from students' constitutional rights generally to Equal Protection specifically, women-including students-are entitled to equal protection under the Fourteenth Amendment and gender

\footnotetext{
49. 393 U.S. 503 (1969).

50. Id. at 506 .

51. Morse v. Frederick, 551 U.S. 393, 396-97 (2007); Bethel Sch. Dist. No. 403 v. Fraser, 478 U.S. 675,682 (1986).

52. See Frank D. LoMonte, Reaching Through the Schoolhouse Gate: Students' Eroding First Amendment Rights in a Cyber-Speech World, AM. CONSTITUTION SOC'Y FOR L. \& POL'Y 1, 3-4, 6 (Feb. 2009), https://www.acslaw.org/files/LoMonte\%20Issue\%20Brief.pdf.

53. Morse, 551 U.S. at 397; Hazelwood Sch. Dist. v. Kuhlmeier, 484 U.S. 260, 261 (1988); Fraser, 478 U.S. at 683.

54. Bd. of Educ. v. Earls, 536 U.S. 822, 822 (2002); Veronia Sch. Dist. 47J v. Acton, 515 U.S. 646, 656 (1995); New Jersey v. T.L.O., 469 U.S. 325, 336-37 (1985). But see Safford Unified Sch. Dist. No. 1 v. Redding, 557 U.S. 364, 365 (2009) (finding strip search of thirteen-year-old student unconstitutional).
}

55. Brown v. Bd. of Educ., 347 U.S. 483, 493 (1954).

is a quasi-suspec ment or are deni tion, the state's ment objective a must be substan tive. ${ }^{57}$ The state justification and burden. ${ }^{58}$ Import than hypothesize tions about the males and fema "archaic," stereot are facially discri tion. ${ }^{60}$

Relying on the challenged schoo or opportunities codes, early Equa tory when they $v$ female students, other hand, impo but not females. ${ }^{63}$

56. United States v

57. Id. at 532-33.

58. Id. at 533 .

59. Id.

60. See Cmtys. for Cir. 2006); Pederson v.

61. See Cmtys. for 1 tection rights via discri Mountain Sch. Dist., 99 injunction ordering a sc junior high school's all to prevail on the merit 1996) (finding a female challenge to school poli tling team).

62. See, e.g., Johns (questioning whether fe N.Y.S.2d 601, 603, 606to wear slacks).

63. See Murphy v. 1 
Equal Protection Title IX of the Civ. line of cases conI will then consid. for school dress

\section{nendment and}

I teach every year hough not always ave constitutional oines Independent urt confirmed that s when they enter e not identical to preme Court cases nstitutional rights stances within the nts' constitutional 4 and Fourteenth

senerally to Equal ents-are entitled dment and gender TITUTION SOC'Y FOR L. \& 620 Issue $\% 20$ Brief.pdf. neier, 484 U.S. 260,261

Sch. Dist. $47 \mathrm{~J}$ v. Acton, 6-37 (1985). But see Saf) (finding strip search of is a quasi-suspect class. ${ }^{56}$ When women receive differential treatment or are denied an opportunity based on a gender classification, the state's classification must serve an important government objective and the means adopted to pursue that objective must be substantially related to the achievement of that objective. "The state must put forward an "exceedingly persuasive" justification and the state alone must satisfy this demanding burden. ${ }^{58}$ Importantly, the justification must be genuine rather than hypothesized and "it must not rely on overbroad generalizations about the different talents, capacities, or preferences of males and females." ${ }^{.59}$ Classifications based on paternalism, or "archaic," stereotypical assumptions about interests and abilities, are facially discriminatory and constitute intentional discrimination. ${ }^{60}$

Relying on these principles, female students have successfully challenged school policies that resulted in differential treatment or opportunities based on sex. ${ }^{61}$ In the context of school dress codes, early Equal Protection cases found them to be discriminatory when they were facially sex-based, for example, prohibiting female students, but not males, from wearing pants ${ }^{62}$ or, on the other hand, imposing hair length requirements on male students, but not females. ${ }^{63}$
56. United States v. Virginia, 518 U.S. 515, 533-34 (1996).

57. Id. at 532-33.

58. Id. at 533 .

59. Id.

60. See Cmtys. for Equity v. Mich. High Sch. Athletic Ass'n, 459 F.3d 676, 694 (6th Cir. 2006); Pederson v. La. State Univ., 213 F.3d 858, 880-81 (5th Cir. 2000).

61. See Cmtys. for Equity, 459 F.3d at 692-95 (association violated females' equal protection rights via discriminatory scheduling of high school sports season); Beattie v. Line Mountain Sch. Dist., 992 F. Supp. 2d 384, 391-95 (M.D. Pa. 2014) (issuing a preliminary injunction ordering a school district to allow a female student-athlete to participate on the junior high school's all male wrestling team and concluding the female student was likely to prevail on the merits of her claim); Adams v. Baker, 919 F. Supp. 1496, 1504 (D. Kan. 1996) (finding a female student was likely to succeed on the merits of sex discrimination challenge to school policy prohibiting female students from participating in all-male wrestling team).

62. See, e.g., Johnson v. Joint Sch. Dist. No. 60, 508 P.2d 547, 548-49 (Idaho 1973) (questioning whether female students have to wear pantsuits); Scott v. Bd. of Educ., 305 N.Y.S.2d 601, 603, 606-07 (N.Y. Sup. Ct. 1969) (questioning whether female students have to wear slacks).

63. See Murphy v. Pocatello Sch. Dist. No. 25, 480 P.2d 878, 879-80 (Idaho 1971). 


\section{Title IX}

Beyond constitutional protection, federal statutory law protects women and girls from discrimination in educational settings. Title IX of the Education Amendments of 1972 prohibits sex discrimination in any federally funded education program or activity. ${ }^{64}$ Like other federal anti-discrimination laws, Title IX prohibits both disparate treatment discrimination and disparate impact discrimination. ${ }^{65}$ Policies that explicitly classify individuals based on sex constitute disparate treatment on the basis of sex and generally will violate Title IX unless the recipient of federal funds can articulate a legitimate, nondiscriminatory reason for such classification. ${ }^{6}$ Consistent with the Equal Protection doctrine discussed above, differential treatment of male and female students based on paternalism and archaic, stereotypical assumptions will constitute intentional sex discrimination under Title IX. ${ }^{67}$

Even in the context of a facially sex-neutral policy, students can establish Title IX sex discrimination by proving disparate impact. ${ }^{68}$ To establish a disparate impact claim, a plaintiff must show that a facially neutral policy had a disproportionate and adverse impact on a protected group. ${ }^{69}$ In response to this claim, the school must articulate a "substantial legitimate justification" for the policy. ${ }^{70}$ The policy must be necessary to meeting an important educational goal that is legitimate and integral to the school's mission; for example, there must be an "educational necessity" for the practice. ${ }^{71}$ Even if the school can satisfy this requirement, it will nevertheless be liable if there exists an "equally effective alternative practice" that would cause less adverse impact. $^{72}$ Proving Title IX sex discrimination under a disparate im-

64. Section 1681(a) provides: "No person in the United States shall, on the basis of sex, be excluded from participation in, be denied the benefits of, or be subjected to discrimination under any education program or activity receiving federal financial assistance." 20 U.S.C. $\$ 1681$ (a) (2012),

65. U.S. DeP’T OF JUSTiCe, Crvil Rights Div., Title IX Legal Manual 57 (2001), http://www.justice.gov/sites/default/files/crt/legacy/2010/12/14/ixlegal.pdf.

66. Id. at 60-63.

67. Pederson v. La. State Univ., 213 F.3d 858, 880-81 (5th Cir. 2000).

68. U.S. Dep't of Justice, supra note 65 , at $63-70$

69. Id. at 65 .

70. Id.

71. Id. at 66 (citations omitted).

72. Id. 
pact challenge to a facially neutral policy may prove challenging for female students, particularly if they seek money damages. ${ }^{73}$

\section{B. The Grooming and Dress Code Cases}

Legal and scholarly analysis of discrimination in grooming and dress codes has been most fully developed in the context of Title VII employment discrimination. ${ }^{74}$ These challenges to dress and grooming codes have frequently involved claims of sex stereotypes as an impermissible basis for discrimination. ${ }^{75}$

Beginning in the 1970s, a number of cases upheld sexdifferentiated dress and grooming policies that were nevertheless "comparable," justified by accepted community norms or standards and were reasonably related to an employer's business needs, unless they either created an unequal burden for one sex or were unequally enforced. ${ }^{76}$ Then in 2006 , the Supreme Court recognized that adverse employment decisions based on sex stereotypes relating to appearance and demeanor will constitute actionable sex discrimination in some circumstances. In Price Waterhouse $v$. Hopkins, the Court found that Price Waterhouse's refusal to promote Ann Hopkins to partner and their instructions to "walk more femininely, talk more femininely, dress more femininely, wear make-up, have her hair styled, and wear jewelry," constituted impermissible sex discrimination based on sex stereotypes. ${ }^{77}$ In considering the legal significance of sex stereotyping, the Court observed "we are beyond the day when an employer could evaluate employees by assuming or insisting that they match the stereotype associated with their group." ${ }^{78}$

But despite high hopes that Price Waterhouse would largely eliminate reliance on sex stereotypes in employment, including dress and grooming standards, ${ }^{79}$ some cases have continued to

es shall, on the basis of be subjected to discrimfinancial assistance." 20 GAL MANUAL 57 (2001), ral.pdf.

73. See Horner v. Ky. High Sch. Athletic Ass'n, 206 F.3d 685, 692 (6th Cir. 2000).

74. Title VII of the Civil Rights Act of 1964, 42 U.S.C. $\$ 2000$-2(a)(1) (2012); see Hayden ex rel A.H. v. Greensburg Cmty. Sch. Corp., 743 F.3d 569, 577 (7th Cir. 2014).

75. A number of early cases upheld sex-differentiated dress and grooming codes. For extensive citation to the sex-differentiated grooming cases, see Hayden, $743 \mathrm{~F} .3 \mathrm{~d}$ at $577-$ 78.

76. Id. at $577-78$ (citing cases).

77. 490 U.S. $228,235,255-58$ (1989).

78. Id. at 251 .

79. See Mary Ann Case, Legal Protections for the "Personal Best" of Each Employee: Title VII's Prohibition on Sex Discrimination, the Legacy of Price Waterhouse v. Hopkins, 
countenance sex-differentiated dress and grooming codes. ${ }^{80}$ The most notorious case in the post-Price Waterhouse line is Jesperson v. Harrah's Operating Co. ${ }^{81}$ There, Darlene Jesperson sued Harrah's for terminating her based on her refusal to wear make-up, arguing that the requirement (and adverse employment action) was based on impermissible sex stereotypes. ${ }^{82}$ The Ninth Circuit found, however, that the make-up requirement was but one small part of a more general overall dress and grooming policy that applied largely the same standards to men and women. ${ }^{83}$

The extent to which earlier sex-differentiated dress and grooming code cases remain good law after Price Waterhouse remains an open question. ${ }^{84}$ There are at least two potential modes of analysis. The first would be to follow the Jesperson and the prePrice Waterhouse cases. ${ }^{85}$ Under that approach, the analysis would consider whether the complained-of-sex-differentiated policy was part of a broader, comprehensive grooming policy imposing comparable standards on both sexes ${ }^{86}$-an even-handed requirement that everyone "look professional." also consider whether sex-differentiated standards were justified by community norms, whether the burdens imposed by those standards were actually comparable, and whether they were enforced equally. ${ }^{88}$

An alternative approach to analyzing challenges to dress and grooming codes would begin with a literal reading of Title IX, as adopted by some courts, the Equal Employment Opportunity Commission ("EEOC"), and also from Price Woterhouse. ${ }^{90}$ Begin-

and the Prospect of ENDA, 66 STAN. L. REV. 1333, 1357 (2014).

80. Id. at 1354-61; Joanna L. Grossman, Sex-Stereotyping and Dress Codes Under Title VII: Why Courts Can't Get it Right, FINDLAW (Mar. 3, 2009), http://writ.news.findlaw. com/grossman/20090303.html.

81. 444 F.3d 1104 (9th Cir. 2006).

82. Id. at $1106-08$.

83. Id. at 1113 .

84. See Hayden v. Greensburg Cmty. Sch. Corp., 743 F.3d 569, 578 (7th Cir. 2014).

85. The Seventh Circuit in Hayden, for example, assumed that line of precedent remained at least mostly unmodified. $I d$.

86. See Hayden, 743 F.3d at 581; Jesperson, 444 F.3d at 1112.

87. Hayden, 743 F.3d at 584 (Manion, J., concurring in part and dissenting in part).

88. Id. at 580 .

89. The EEOC is the federal agency responsible for enforcing federal laws prohibiting employment discrimination based on race, color, religion, sex, national origin, age, disability, or genetic information. About the EEOC, U.S. EQUAL OPPORTUNITY EMP. COMM'N (Jan. 2016), http://www.eeoc.gov/eeoc/.

90. Price Waterhouse v. Hopkins, 490 U.S. 228, 258 (1989). 
ming codes. ${ }^{80}$ The e line is Jesperson sperson sued Harto wear make-up, nployment action) The Ninth Circuit was but one small ing policy that apmen. ${ }^{83}$

dress and groomaterhouse remains otential modes of erson and the preach, the analysis differentiated polining policy imposeven-handed rehe analysis would rds were justified imposed by those her they were en-

nges to dress and ing of Title IX, as nent Opportunity uterhouse. ${ }^{90}$ Begin-

d Dress Codes Under Tihttp://writ.news.findlaw.

578 (7th Cir. 2014). at line of precedent re-

dissenting in part).

federal laws prohibiting onal origin, age, disabilNITY EMP. COMM'N (Jan. ning with the language of Title IX itself, the statute clearly prohibits discrimination based on sex. ${ }^{91}$ Thus, dress codes that are facially differentiated based on sex would contravene the plain language of the statute. ${ }^{92}$ Consistent with this reading, an early decision by the $\mathrm{EEOC}$ found sex-based hair length requirements unlawful in the absence of a bona fide occupational qualification. ${ }^{93}$ Likewise, Price Waterhouse can be read to stand for the proposition that sex stereotypes are an impermissible basis for developing dress and grooming policies. ${ }^{94}$ On this reading, the fact that both sexes must comply with a comprehensive grooming code would not necessarily preclude a finding of sex discrimination if that policy included gender-specific requirements based on sex stereotypes. ${ }^{95}$ Likewise, comprehensive grooming policies may impose unequal burdens on men versus women and therefore constitute sex discrimination. ${ }^{96}$

In the public school dress code cases, the facts that indicate sex stereotyping, and hence sex discrimination, take on a different character. Rather than a policy requiring students to dress a certain way because of sex stereotypes (as was the case in Jesperson, for example), the female students in these instances are alleging sex discrimination via prohibitions on certain types of student dress because of stereotypes associated with those types of dress. ${ }^{97}$ For the APA, dress code enforcement may inappropriately impose sexuality on gixls. ${ }^{98}$ There are a few analogous cases in the Title VII context. But in a case in which female employees were admonished not to wear jeans, tight clothes, or show cleavage, a

91. 20 U.S.C. § 1681(a) (2012).

92. Cf. Case, supra note 79, at 1338-42, 1354-55; Grossman, supra note 80 (highlighting the congressional debate about the language in Title VII and how courts have actually come to interpret the language).

93. EEOC Decision No. 72-1380, 4 Fair Empl. Prac. Case (BNA) 846 (Mar. 17, 1972) The EEOC's Compliance Manual, however, currently permits dress codes that are "applied evenly" to both sexes, including dress codes that have different requirements for males and females, provided they are "equally enforced" and "the requirements are equivalent for men and women with respect to the standard or burden that they impose." EEOC Compl. Man. (BNA) § 619.4(d) (Aug. 2009).

94. See Case, supra note 79, at 1334-35; Grossman, supra note 80; supra notes 55-57 and accompanying text.

95. See Jesperson v. Harrah's Operating Co., 444 F.3d 1104, 1115-16 (9th Cir. 2006) (Pregerson, J., dissenting).

96. Id. at 1117 (Kozinski, J., dissenting).

97. See, e.g., Johnson v. Joint Sch. Dist. No. 60, 508 P.2d 547, 549 (Idaho 1973); Scott v. Bd. of Ed., 305 N.Y.S.2d 601, 603, 606 (N.Y. Sup. Ct. 1969).

98. See APA, supra note 14 , at 1 . 
court found that despite disparate enforcement of a dress code based on sex, the claim did not constitute sex discrimination because the disparate treatment was prompted by legitimate, nondiscriminatory concerns about institutional security at an allmale correctional facility. ${ }^{99}$ And in another case, a court found that a judge's unwritten dress code that all employees conform to a "Brooks Brothers look," and her reprimanding an employee for wearing excessive make-up and her hair down, did not constitute sex discrimination because the grooming standards were applied in an even-handed way and were reasonably related to business needs. ${ }^{100}$

\section{Questions Raised in the Legal Context}

The viability of a colorable challenge to school dress codes based on sex stereotypes depends on several overarching issues. First, generally, how will courts construe students' Equal Protection rights in schools? Second, and more specifically, how closely will courts scrutinize schools' justifications for dress codes that impose disparate treatment or have a disparate impact based on sex? Finally, how will courts weigh the impact and enforcement of sex-based dress codes?

\section{The Scope of Students' Equal Protection Rights in Schools}

As discussed above, although the Supreme Court has long recognized students' constitutional rights, it has been equally clear that students' constitutional rights in schools are not coextensive with those of adults in other settings. ${ }^{101}$ For purposes of Equal Protection analysis, a threshold question concerns the scope of female students' Equal Protection rights in the school setting.

As indicated above, in general, the Court has tended to emphasize reasonableness ${ }^{102}$ and deference to school administrators when considering constitutional challenges to school policies. ${ }^{103}$

\footnotetext{
99. Givens v. Chambers, 548 F. Supp. 2d 1259, 1266, 1273-74 (M.D. Ala. 2008).

100. Wislocki-Goin v. Mears, 831 F.2d 1374, 1379-80 (7th Cir. 1987).

101. See Bethel Sch. Dist. No. 403 v. Fraser, 478 U.S. 675, 683 (1986).

102. See, e.g., New Jersey v. T.L.O., 469 U.S. 325, 341-42 (upholding student search based on reasonableness under all the circumstances rather than probable cause or warrant).

103. See Safford Unified Sch. Dist. No. 1 v. Redding, 557 U.S. 364, 371 n.1 (2009) (" $[\mathrm{S}]$ tandards of conduct for schools are for school administrators to determine without se-
}

The Court's Firs shed some light lenges to schoc speech often imy challenges prom of restrictions of the conduct in $\mathrm{g}$ with schoolwork has held that su ferentiated fear tended to split c of past interfer which for any volves substanti course, not imm lic schools' broa cluding "the bou sequently, the decisions to sanc

cond-guessing by cour 377 (recognizing "the fessional judgment"); education of the Nati state and local schoo Dist., 393 U.S. 503, 5 officials ... to prescrib 104. See Tinker, 39 105. Id.

106. Id. at 508.

107. Compare Har 2013) (prohibiting a flag's history of spark 538 F.3d 554, 565 (6th caused "minimal" inst sonably forecast" that F.3d 1246, 1249 (11th presented evidence of Rewt v. Madison Cty. court's decision that $\mathrm{s}$ cause, inter alia, the disruption).

108. Tinker, $393 \mathrm{U}$ 109. See Bethel Sc public education must a democratic society). 110. Id. at 685 . 
of a dress code scrimination belegitimate, nonurity at an alle, a court found oyees conform to an employee for id not constitute cds were applied ated to business

1ool dress codes rarching issues. is' Equal Protecally, how closely dress codes that impact based on d enforcement of

\section{in Schools}

urt has long recen equally clear not coextensive rposes of Equal ns the scope of nool setting.

ended to emphaadministrators chool policies. ${ }^{103}$

The Court's First Amendment cases are instructive, and perhaps shed some light on how courts might respond to sex-based challenges to school dress codes. Although restrictions on adult speech often implicate strict scrutiny, students' First Amendment challenges prompt a more deferential analysis. ${ }^{104}$ Even in the face of restrictions of "pure" speech, school discipline will be upheld if the conduct in question "materially and substantially" interferes with schoolwork and discipline. ${ }^{105}$ Although the Supreme Court has held that such discipline must be based on more than "undifferentiated fear or apprehension of disturbance," courts have tended to split on whether school districts must provide a record of past interference. ${ }^{107}$ By contrast, "conduct by the student... which for any reason... materially disrupts classwork or involves substantial disorder or invasion of the rights of others is, of course, not immunized ...."108 These cases have emphasized public schools' broader authority to educate students as citizens, including "the boundaries of socially appropriate behavior." sequently, the Court has had little problem upholding school decisions to sanction "offensively lewd and indecent" behavior. ${ }^{110}$

cond-guessing by courts lacking the experience to appreciate what may be needed."); $i d$. at 377 (recognizing "the high degree of deference that courts must pay to the educator's professional judgment"); Hazelwood Sch. Dist. v. Kuhlmeier, 484 U.S. 260, 273 (1988) ("[T]he education of the Nation's youth is primarily the responsibility of parents, teachers, and state and local school officials, and not of federal judges."); Tinker v. Des Moines Sch. Dist., 393 U.S. 503, 507 (1969) (recognizing the "comprehensive authority of . . school officials ... to prescribe and control conduct in the schools").

104. See Tinker, 393 U.S. at 513.

105. Id.

106. Id. at 508 .

107. Compare Hardwick ex rel. Hardwick v. Heyward, 711 F.3d 426, 437-440 (4th Cir. 2013) (prohibiting a student from wearing Confederate flag shirts based in part on the flag's history of sparking racial tensions and commotion among students), Barr v. Lafon, 538 F.3d 554, 565 (6th Cir. 2008) (conceding that if the record showed the Confederate flag caused "minimal" instances of prior disruption, then the school would not be able to "reasonably forecast" that the flag would cause material disruption), and Scott v. Sch. Bd., 324 F.3d 1246, 1249 (11th Cir. 2003) (upholding a ban on Confederate flags because the school presented evidence of racially based fights and racial tensions), with Castorina ex rel. Rewt v. Madison Cty. Sch. Bd., 246 F.3d 536, 543-44 (6th Cir. 2001) (reversing the lower court's decision that students wearing Confederate flag clothing was protected speech because, inter alia, the school board failed to demonstrate that racial symbols caused actual disruption).

108. Tinker, 393 U.S. at 513.

109. See Bethel Sch. Dist. No. 403 v. Fraser, 478 U.S. 675, 681 (1896) (explaining that public education must prepare students with the habits and manners necessary to serve in a democratic society).

110. Id. at 685 
This deference to school administration has been invoked specifically in cases challenging school dress requirements as sex discrimination. ${ }^{111}$ In the context of First Amendment challenges, for example, the Eleventh Circuit ruled that in the high school environment there is a "per se rule that [grooming regulations] are constitutionally valid." 112 And in Tinker, the Court indicated that it might have less constitutional concern with school dress or grooming codes as opposed to content-based restrictions on pure speech. ${ }^{113}$

These cases suggest that courts might afford officials more leeway in school sex discrimination cases than in other adult contexts. As such, whether a school's justification for a sex-based dress code needs to be "exceedingly persuasive," for example, is an open question. If courts view the dress code cases consistently with other cases that consider the constitutional rights of public school students, any resulting Equal Protection analysis likely would be less stringent than in other contexts.

\section{Evaluating Schools' Justifications for Differential Treatment or Impact of Sex-Based Dress Codes}

Schools, of course, can offer a number of legitimate, pedagogical concerns that might be implicated by student dress, such as promoting respect for self, others, and authority, student safety and protection, and exposing students to expectations about professional dress. ${ }^{114}$ Sexual harassment is a special concern. ${ }^{115}$ Yet episodes of enforcement have far too often been reportedly accompanied with commentary that raises concerns about the validity of school motives. ${ }^{116}$ Students frequently report that they are

111. See Youngblood v. Hillsborough, No. 8:02-CV-1098-T-24MAP, slip op. at 8-11 (M.D. Fla. Sept. 25, 2002) (deferring to school administration in absence of allegation of fundamental rights violation). But the court specifically notes it does not implicate denial of opportunity to attend classes or obtain equal opportunity education. Id. at 6 .

112. Davenport v. Randolph Cty. Bd. of Educ., 730 F.2d 1395, 1397 (11th Cir. 1984) (quoting Karr v. Schmidt, 460 F.2d 609, 617 (5th Cir. 1972)).

113. See Tinker, 393 U.S. at 507-08 (contrasting "regulation of the length of skirts or the type of clothing" with "direct, primary First Amendment rights akin to 'pure speech"').

114. See, e.g., Todd A. Mitchell et al., Dress Codes in the Public Schools: Principals, Policies, and Precepts, 29 J.L. \& EDUC. 31, 39-42, 44-45 (2000) (providing a study indicating why schools employ dress codes).

115. Under Title IX, schools have a duty to prevent and protect against sexual harassment in schools. 20 U.S.C. $\S 1681$ (a); David v. Monroe Cty. Bd. of Ed., 526 U.S. 629, 63949 (1999).

116. See, e.g., Caroline Bologna, The Ridiculous Dress Code Rule That Made This 
disciplined for dress code violations because they are "too distracting" for male students, teachers, and administrators. ${ }^{117}$ And they are told to cover up, suggesting that their bodies are inappropriate, dangerous, and subject to judgment. ${ }^{118}$

In the context of sex discrimination, justifications based on "moral beliefs" will not generally rise to the level of an important government objective. ${ }^{119}$ Instead, courts have found that in the context of gender-based classifications, students' moral opprobrium is not an exceedingly persuasive justification because "it is not the duty of the school to shield students from every situation which they may find objectionable or embarrassing . . ." Moreover, consistent with Tinker, courts have found that avoiding disruption is not a sufficient justification for gender-based classifications absent evidence supporting the existence or likelihood of actual disruption. ${ }^{121}$ And finally, even when a school is concerned about the potential for inappropriate behavior and sexual harassment, ${ }^{122}$ courts have found that they must supply more than conclusory allegations to support this justification. ${ }^{123}$ As one court put it "[a] school district best avoids sexual harassment litigation by acting to prevent sexual harassment rather than excluding females from participating in activities." ${ }^{24}$ In the context of student dress, the APA's admonition regarding harassment is worth repeating: "girls do not 'cause' harassment of abusive behavior by wearing sexy clothes; no matter what girls wear, they have the

Teen's Outfit 'Inappropriate', HufFINGTon Post (Aug. 19, 2015, 3:21 PM), http:/www. huffingtonpost.com/entry/ridiculous-dress-code-rule-that-made-teen-outfit-inappropriate_ $55 \mathrm{~d} 34 \mathrm{e} 04 \mathrm{e} 4 \mathrm{b0ab} 468 \mathrm{~d} 9 \mathrm{e} 6 \mathrm{fa}$ (describing an incident where a high school student's mother had to bring her daughter a scarf on the first day of school because her outfit revealed her collarbone); Eun Kyung Kim, Teen Asked to Cover Up at School Dance: 'It Made Me Feel Like I Wasn't Good Enough', TODAY (Jan. 28, 2015, 4:43 PM), http://www.today.com/par ents/utah-girl-asked-cover-over-dress-code-violation-felt-embarrassed-2D80453387 (discussing an instance where a girl put on her winter coat at her school dance because her dress did not cover at least two inches across each shoulder).

117. See Bologna, supra note 116 (describing a mother's frustrations that girls could not expose their collarbones because "it may distract their male class mates [sic]").

118. See Orenstein, supra note 9.

119. Adams ex rel. Adams v. Baker, 919 F. Supp. 1496, 1504 (D. Kan. 1996); see Beattie v. Line Mountain Sch. Dist., 992 F. Supp. 2d 384, 395 (M.D. Pa. 2014).

120. Beattie, 992 F. Supp. 2d at 394-95 (quoting Adams, 919 F. Supp. at 1504).

121. Adams, $919 \mathrm{~F}$. Supp. at 1504 (noting that the fact that some boys might quit wrestling team if the plaintiff was allowed to participate does not constitute evidence of disruption).

122. See APA, supra note 14 , at 16 (indicating that research confirms sexual harassment in school settings is routine for many girls).

123. See Beattie, F. Supp. 2 d at 394.

124. Adams, 919 F. Supp. at 1504. 
right to be free of sexual harassment, and boys and men can and should control their behavior."

The dress code cases also emphasize that one measure of the validity of sex-based dress codes is whether they are justified by community norms. Although it is not clear how searching courts might be in evaluating this question, in a recent school dress code challenge, the Seventh Circuit acknowledged that appearance norms for girls and boys can and have evolved over time ${ }^{126}$ and indicated it might expect that school dress policies would reflect this evolution. ${ }^{127}$ Community norms might therefore call into question sex-based dress codes if they reflect anachronistic ideas about "appropriate" attire for girls (think back to the prohibition on wearing pants). There may be reasons, however, not to be entirely sanguine about community norms. To the extent that sexualization of girls has impacted broader social assumptions and expectations, for instance, community norms may automatically incorporate sexualized assumptions about girls' bodies, reinforcing images of distracting female bodies that should be covered up.

\section{Evaluating the Impact and Enforcement of Sex-Based Dress Codes}

Finally, the dress code cases also consider the extent to which sex-differentiated policies are truly comparable and whether they impose unequal burdens based on sex. The substantive content of dress codes might well implicate comparability. Consider, for example, a policy that prohibits dress choices more frequently exercised by female students rather than males. Does a dress code really impose comparable standards on girls and boys when it bans leggings and yoga pants?

Even in the context of facially neutral dress policies, multiple anecdotes suggest that the implementation and enforcement of school dress codes frequently impose unequal burdens on female students. ${ }^{128}$ The Maggie Walker scenario discussed in the Introduction is just one example. There, school officials explicitly sin-

125. APA, supra note 14, at 33 .

126. See Hayden ex rel A.H. v. Greensburg Cmty. Sch. Corp., 743 F.3d 569, 582 (7th Cir. 2014) ("In 2014, it is not obvious that any and all hair worn over the ears, collar, or eyebrows would be out of the mainstream among males ....").

127. See id. at 581-82.

128. Zhou, supra note 30 . 
measure of the are justified by searching courts chool dress code hat appearance over time ${ }^{126}$ and es would reflect refore call into achronistic ideas the prohibition er, not to be enxtent that sexussumptions and ay automatically bodies, reinforcd be covered up.

\section{-Based Dress}

extent to which nd whether they antive content of Consider, for exfrequently exera dress code reys when it bans

olicies, multiple enforcement of rolens on female ed in the Introls explicitly sin- gled out girl students for the spotcheck, and the disciplinary consequences targeted only girls; if ten girls were found to be in violation, then all girls would be prohibited from wearing shorts for one day. ${ }^{129}$ Other examples of unequal burden include policies enforced only against "more developed" girl students, or holding a mandatory school assembly for girls only to discuss yoga pants and leggings. ${ }^{130}$

The disciplinary measures employed also seem likely to inflict unequal burdens on girls: girls, not boys, are removed from class and miss valuable learning opportunities; girls, not boys, are sent home to change, missing even more school interactions; girls, not boys, are forced to wear "shame suits" after having been found in violation of school dress policy. All these factors suggest that even when schools can articulate legitimate and non-discriminatory justifications for their dress policies, their methods of implementation and enforcement raise serious sex-discrimination concerns. At a minimum, under Title IX, schools would be required to consider the existence of equally effective alternative practices that might further its goals.

Armed with this more complete understanding of the cultural and legal contexts in which contemporary dress code debates arise, I turn finally to some concluding thoughts on what schools and students might learn from these contexts and how they might inform dress code policy, implementation, and alternatives.

\section{Moving ForWARD: PUBLIC SCHOOL DRESS CODES IN CONTEXT}

Regardless of whether litigation develops in this latest wave of school dress code challenges, schools and students can draw valuable lessons from the larger contexts-both cultural and legal-in which these debates are situated. I consider, first, what insights we might apply to the design and implementation of dress codes

129. Chris Thomas, "Short Shorts" Protest at Maggie Walker to Bring Reforms, NBC12 (Oct. 24, 2014, 11:40 PM), http://www.nbc12.com/story/26786975/dress-code-protest-atmaggie-walker-to-bring-reforms.

130. See, e.g., Dockterman, supra note 5; Annie-Rose Strasser \& Tara Culp-Ressler, How 'Slut Shaming' Has Been Written into School Dress Codes Across the Country, THINKPROGRESS (May 6, 2013, 3:00 PM), http://thinkprogress.org/health/2013/05/06/1969 001/slut-shaming-dress-codes/. 
and then turn to explore potential alternatives to dress codes that would foster similar goals.

\section{A. Designing Public School Dress Codes}

First, consistent with female students' own experiences and scholarly opinion, school administrators should understand that they develop and implement school dress code policy within a broader cultural setting that too frequently sexualizes females and blames them for unwanted sexual attention and harassment. Indeed, the sexualization of girls as a cultural phenomenon in the United States has reached such epidemic proportions that it prompted the APA to create a Task Force on the Sexualization of Girls in response to widespread concern. ${ }^{131}$

The first step is to increase awareness of these trends among school administrators, teachers, and staff, and the APA Task Force's Report on the Sexualization of Girls is an excellent place to start. Beyond increasing awareness, teachers and administrators can play an active role in either perpetuating or counteracting the impact of sexualization on their students. For instance, studies suggest that teachers may unwittingly contribute to the sexualization of girls; ${ }^{132}$ they might consider the extent to which "dress coding" perpetuates sexualization. Administrators should also encourage faculty to examine the curriculum for implicit messages about the value of girls. ${ }^{133}$ But schools and formal education can also be an important check against the harms of sexualization for girls. Indeed, the APA describes a number of school initiatives that can help counteract sexualization, including media literacy programs, athletics, extracurricular activities, and comprehensive sex education ${ }^{134}$

Second, in terms of the development and enforcement of school dress codes, both the Equal Protection doctrine and Title IX precedent state that schools should work to avoid facially sexdifferentiated standards. This means that dress codes should apply with equal force to boys and girls and students of all stages of

131. See APA, supra note 14, at 1.

132. Id. at $15-16$.

133. Jennifer R. Curry \& Laura H. Choate, The Oversexualization of Young Adolescent Girls: Implications for Middle School Educators, 42 MIDDLE SCH. J. 6, 10 (2010).

134. APA, supra note 14, at 35-37. For additional interventions, see Curry \& Choate, supra note 133 , at $10-13$. 
physical development. And they should be implemented and enforced consistently across these student populations. Further, schools should consider whether particular proscriptions-on things like skirts, leggings, or yoga pants-will have a disproportionate impact on female students, even when written in a sexneutral fashion. And schools must take care to actually enforce these policies against both male and female students. The Maggie Walker practice of singling out female students for shorts-checks and potential discipline, for example, should have raised clear concerns about unequal burdens.

Third, whether considered through the lens of Equal Protection or Title IX, schools should reflect carefully on their justifications for promulgating these policies. In particular, they should examine whether their motivations are based on stereotypical assumptions about girls' bodies, female dress, and the preferences or reactions to female dress by both males and females. To the extent their dress codes are based on community norms, they should critically examine the basis for these judgments and be mindful that the norms can evolve over time. One way to ensure student dress codes in fact reflect community norms is to involve the students themselves in the process. Initiating a school-wide conversation about the purposes and content of school dress codes would provide students with a voice in these deliberations and create a platform for discussing the potential concerns that dress codes raise for students. ${ }^{135}$

Fourth, school communities-students, parents, and administrators-must use reasonableness and discretion as their guides. The fact that there is less concern about student dress among elementary school principals than middle school and high school administrators, ${ }^{136}$ for example, might suggest that monolithic, district-wide policies are too blunt when elementary schools send home kindergarteners for wearing sundresses to school. ${ }^{137}$ For their part, students can critically question the implicit messages imbedded in dress codes while also being more respectful of the

135. One gender studies expert recommends that schools involve students themselves in deliberations over dress codes. See, e.g., McMahon, supra note 37.

136. Mitchell et al., supra note 114, at 45.

137. See, e.g., Carol Christian, Houston-Area Dad Says His Little Girl's Sundress Didn't Pass School Muster, Hous. CHRON. (Apr. 29, 2015, 4:07 PM), http://www.chron.com/hous ton/article/Houston-area-dad-says-his-little-girl-s-sundress-6229256.php. 
legitimate pedagogical goals pursued by school administrators with regard to student dress.

Armed with these insights, school communities could come together to draft new school dress policies that would avoid many of the concerns discussed above. These new codes, for example, might remove any explicit references to sex or gender, and focus instead on the school's pedagogical mission. Following Tinker, they could prohibit clothing that actually causes a material or substantial disruption or distraction and require that the disruption be documented in writing. ${ }^{138}$ They could base understandings of "distraction" to focus on clothing that negatively impacts student engagement by restricting full range of motion or requiring frequent readjustment, rather than assumptions about how it might impact others. And they could apply equally to everyone in the school community-students and personnel. ${ }^{139}$

\section{B. Alternatives to Student Dress Codes}

Moving beyond dress codes, disparate impact analysis asks whether equally effective alternative practices exist to vindicate legitimate school goals. Consider the potential goals I listed above: promoting respect for self, others, and authority; student safety and protection; and exposing students to expectations about professional dress.

To the extent these goals implicate concerns relating to sexualization and harassment, schools are in an excellent position to be an important check against them. Student education and the availability of an open and frank conversation about the issues can act as a powerful antidote to the sexism and sexualization that are of concern to many female students. Rather than prohibiting particular types of student dress, teachers, administrators, and students might talk about student dress in the broader context of sexualization. Conversations might include: the importance of respecting one's own body and those of others; the im-

138. Under Pressure, Suffolk School Board Backs Off Discriminatory Gender-Based Dress Code Policy, ACLU (Mar. 5, 2012), https://www.aclu.org/news/under-pressure-suffo lk-school-board-backs-discriminatory-gender-based-dress-code-policy. See generally Emily Satchell, Students at Maggie Walker Governor's School Have Come Up with Their Own Dress Code, WRIC (Sept. 2, 2015, 5:49 AM), http://wric.com/2015/08/28/students-at-maggi e-walker-governors-school-have-come-up-with-their-own-dress-code/ (discussing the school director's interest in letting students provide input for the dress code).

139. See Satchell, supra note 138. 
portance of appropriate dress in the development of professional identity and success; the impact of sexualization on both boys and girls; and the profound impacts of bullying, leering, and harassing. Additionally, following the lead of the APA, schools might implement media literacy programs to encourage critical evaluation of how the media portrays girls.

Moving beyond educational initiatives, other alternatives may successfully vindicate comparable goals without risking the sexual opprobrium raised by dress code policies. For instance, school uniforms might address many of the same underlying concerns, but in a more sex-neutral manner. ${ }^{140}$ As observed by the APA, "when sexualized clothing is part of a larger cultural context in which girls are sexually objectified, standardized uniforms may help to change those cultural messages and understandings of who girls are and what they are capable of, thereby reducing the incidence of sexual harassment."

\section{CONCLUSION}

act analysis asks exist to vindicate al goals I listed uthority; student to expectations

celating to sexuallent position to be ducation and the about the issues and sexualization ther than prohib$\mathrm{s}$, administrators, the broader coninclude: the imof others; the im-

iminatory Gender-Based ews/under-pressure-suffo icy. See generally Emily me Up with Their Own 108/28/students-at-maggi e/ (discussing the school de).

Soon after the PA announcement at the Maggie Walker School in Richmond, a student protest ensued. ${ }^{142}$ Male students came to school weaxing the shortest shorts they could find, and female students came dressed as modestly as possible. ${ }^{143}$ Their protest not only made a powerful point about the problematic, sex-based assumptions and enforcement of the school's dress code, but it also generated change. The principal invited student input about contemporary community standards concerning appropriate high school dress. ${ }^{144}$ As a result, the new dress code focuses on interferences and disruptions to the school environment. It accommodates contemporary fashion and student expression including yo-

140. School uniforms are one mechanism by which parents and teacher can counteract the power of media and commercialism in shaping children's identities and experiences. See Ann Bodine, School Uniform and Discourses on Childhood, 10 CHILDHOOD 43, 60 (2003). They can also reduce economic disparities and social exclusion. Id. Although school uniform policies have also been challenged on First Amendment grounds, they are typically upheld against such challenges. See A.M. ex rel. McAllum v. Cash, 585 F.3d 214, 224 (5th Cir. 2009); Jacobs v. Clark Cty. Sch. Dist., 526 F.3d 419, 422 (9th Cir. 2008); Blau v. Fort Thomas Pub. Sch. Dist., 401 F.3d 381, 390 (6th Cir. 2005). A complete exploration of the issues raised by mandatory school uniforms is beyond the scope of this essay.

141. APA, supra note 14, at 33 .

142. Ballou, supra note 2 .

143. Id.

144. See Satchell, supra note 138. 
ga pants and leggings, ${ }^{145}$ but prohibits exposed midriffs and undergarments. ${ }^{146}$ And it applies equally to all students and school personnel. ${ }^{147}$

The latest wave of school dress code disputes raises important new questions about sexualization and sex discrimination. School administrators, parents, and students have a tricky set of issues to navigate. But these new concerns also open up new educational opportunities for all members of the school community-a space to talk candidly about sexualization, sex stereotypes, and harassment. These conversations can lead to increased awareness and more mindful action on these issues, as well as updated school dress policies that are fair, pedagogically driven, genderneutral, and accepted as legitimate by all members of the school community.

145. Id. (allowing leggings to be worn with a thumb-length top).

146. Id.

147. Id. 